\title{
Pelatihan kesehatan jiwa terhadap pengetahuan dan sikap keluarga dalam merawat pasien dengan skizofrenia
}

\author{
Rahma Elliya ${ }^{1}$, Sri Haryani², Triyoso $^{3}$ \\ 1Program Studi Ilmu Keperawatan Fakultas Kedokteran Universitas Malahayati Bandar Lampung. \\ Email: bundaauliyusri@yahoo.co.id \\ 2UPTD Puskesmas Sidorejo Kecamatan Sekampung Udik Kabupaten Lampung Timur \\ Email: haryanisri3599@gmail.com \\ ${ }^{3}$ Akademi Keperawatan Malahayati Bandar Lampung. Email: triyosoalip@gmail.com
}

\author{
Abstract \\ Family work with patients suffering from schizophrenia: the impact of training \\ on psychiatric family's attitude and knowledge
}

Background: Based on data from Puskesmas Sidorejo, in 2015 had 16 cases with 14 people $(87.5 \%)$ with schizophrenia and 2 people (12.5\%) with dementia. In 2016 found 14 cases with schizophrenics, and developed in 2017 into 35 cases with 34 people (97.1\%) with schizophrenia and 1 person (2.9\%) with dementia, and in 2018 based on the latest data 42 cases with 41 people $(97.6 \%)$ with Schizophrenia sufferers and 1 person $(2.3 \%)$ with dementia sufferers.

Purpose: To examine family work with patients suffering from schizophrenia: the impact of training on psychiatric family's attitude and knowledge

Methods: The type of research was quantitative with a quasi-experimental design. The objects in this study are families with mental patients, subjects in this study were knowledge and attitudes before and after health education. The sample were 20 respondent and data collection by questionnaires.

Results: The group after being given health education had increase in the level of knowledge with a different of 7,7 , with statistical results obtained t-test $>t$ table, 23.106 $>1.684$, $p$-value $=0,000$ ( $p$-value $<a=0,05$ ), and the group after being given health education had increase in attitude with a different of 26,7 , with statistical results obtained t-test $>\mathrm{t}$ table, 23.106 $>1.684$, $p$-value $=0,000$ ( $p$-value $<a=0,05$ ).

Conclusion: There was family work with patients suffering from schizophrenia: the impact of training on psychiatric attitude and knowledge.

\section{Keywords: Mental health training; Family; Knowledge; Attitude; Schizophrenia}

Latar Belakang: Berdasarkan data dari UPTD Puskesmas Sidorejo, pada tahun 2015 ada 16 kasus dengan 14 orang $(87,5 \%)$ penderita Skizofrenia dan 2 orang $(12,5 \%)$ dengan dimensia. Tahun 2016 ditemukan 14 kasus dengan penderita Skizofrenia. Pada tahun 2017 berkembang menjadi 35 kasus dengan 34 orang $(97,1 \%)$ penderita Skizofrenia dan 1 orang $(2,9 \%)$ dengan dimensia, dan di tahun 2018 berdasarkan data terakhir sebanyak 42 kasus dengan 41 orang $(97,6 \%)$ dengan penderita Skizofrenia dan 1 orang $(2,3 \%)$ dengan penderita dimensia.

Tujuan: Diketahui pelatihan kesehatan jiwa terhadap pengetahuan dan sikap keluarga dalam merawat pasien skizofrenia.

Metode: Jenis penelitian adalah kuantitatif dengan jenis rancangan quasi eksperimen, objek dalam penelitian ini keluarga dengan pasien gangguan jiwa, subjek dalam penelitian ini adalah pengetahuan dan sikap sebelum dan setelah dilakukan pelatihan kesehatan. Sampel sebanyak 20 responden dan pengambilan data dengan kuesioner. 
Pelatihan kesehatan jiwa terhadap pengetahuan dan sikap keluarga dalam merawat pasien dengan skizofrenia

Hasil: Berdasarkan hasil diketahui pada kelompok sesudah diberikan pelatihan kesehatan memiliki kenaikan tingkat pengetahuan dengan selisih 7.7, dengan hasil uji statistik didapatkan $t$-test $>t$ tabel, $23.106>1.684, p$-value $=$ 0,000 ( $p$-value $<a=0,05$ ). Serta pada kelompok sesudah diberikan pelatihan kesehatan memiliki kenaikan sikap dengan selisih 26.7. Hasil uji statistik didapatkan $t_{\text {-test }}>t_{\text {tabel, }}, 23.106>1.684, p$-value $=0,000$ ( $p$-value $<a=0,05$ ).

Simpulan: Ada pengaruh pelatihan kesehatan jiwa terhadap pengetahuan dan sikap keluarga dalam merawat pasien skizofrenia.

\section{Kata kunci: Pelatihan kesehatan jiwa; Keluarga; Pengetahuan; Sikap; Skizofrenia}

\section{PENDAHULUAN}

Kesehatan Jiwa adalah kondisi dimana seorang individu dapat berkembang secara fisik, mental, spiritual, dan sosial sehingga individu tersebut menyadari kemampuan sendiri, dapat mengatasi tekanan, dapat bekerja secara produktif, dan mampu memberikan kontribusi untuk komunitasnya. Pasien dengan gangguan jiwa adalah orang yang mengalami gangguan dalam pikiran, perilaku, dan perasaan serta dapat menimbulkan penderitaan dan hambatan dalam menjalankan fungsi orang sebagai manusia, mempunyai masalah fisik, mental, sosial, pertumbuhan dan perkembangan, dan/atau kualitas hidup sehingga memiliki risiko mengalami gangguan jiwa (Kementrian Hukum Dan Hak Asasi Manusia, 2014). Gangguan jiwa dimana kondisi kesehatan yang melibatkan perubahan dalam pemikiran, emosi atau perilaku ataupun kombinasi dari keduanya (Lokko, Chen, Parekh, \& Stern, 2016).

Pada Era Globalisasi dan persaingan bebas ini kecenderungan terhadap peningkatan gangguan jiwa semakin besar, hal ini disebabkan karena stresor dalam kehidupan semakin kompleks. Peristiwa kehidupan yang penuh tekanan seperti kehilangan orang yang dicintai, putusnya hubungan sosial, pengangguran, masalah dalam pernikahan, kesulitan ekonomi, tekanan di pekerjaan dan diskriminasi meningkatkan risiko penderita gangguan jiwa (Suliswati, Jeremia, Yenny, \& Sumijatun, 2011).

Penderita gangguan jiwa sering mendapatkan stigma dan diskriminasi yang lebih besar dari masyarakat disekitarnya dibandingkan individu yang menderita penyakit medis lainnya. Tidak hanya menimbulkan konsekuensi negatif terhadap penderitanya tetapi juga bagi anggota keluarga, meliputi sikap-sikap penolakan, penyangkalan, dan disisinkan. Penderita gangguan jiwa mempunyai risiko tinggi terhadap pelanggaran hak asasi manusia (Husmiati, 2016).
Masalah gangguan jiwa di seluruh dunia sudah menjadi masalah yang sangat serius. WHO memperkirakan jumlah penduduk didunia yang mengalami depresi diperkirakan 4,4\%. Total jumlah penduduk sekitar 322 juta orang mengalami gangguan depresi. Diperkirakan penduduk yang mengalami depresi meningkat sampai $18,4 \%$. Proporsi jumlah penduduk yang mengalami gangguan kecemasan 3,6\% Total jumlah penduduk sekitar 264 juta orang mengalami gangguan kecemasan, dan meningkat sampai 14,9\% (World Health Organization, 2017).

Jumlah penderita gangguan jiwa di Indonesia mencapai lebih dari 28 juta orang, dengan kategori gangguan jiwa ringan $11,6 \%$ dari populasi dan $0,46 \%$ menderita gangguan jiwa berat atau 46 per mil. $14,1 \%$ penduduk Indonesia mengalami gangguan jiwa dari yang ringan hingga berat, kondisi ini diperberat melalui aneka bencana alam yang terjadi di hampir seluruh wilayah Indonesia. Data jumlah penderita gangguan jiwa di Indonesia terus bertambah, data dari 33 rumah sakit jiwa (RSJ) di seluruh Indonesia hingga kini jumlah penderita gangguan jiwa berat mencapai 2,5 juta orang. $11,6 \%$ penduduk Indonesia yang berusia diatas 15 tahun mengalami gangguan mental emosional atau berkisar 19 juta penduduk. Sebesar $0,46 \%$ diantaranya bahkan mengalami gangguan jiwa berat atau sekitar 1 juta penduduk (Kementerian Kesehatan Republik Indonesia, 2014).

Jumlah seluruh RT yang dianalisis adalah 9.325 terdiri dari 33.440 ART yang berasal dari semua umur. Rumah tangga yang menjawab memiliki ART dengan gangguan jiwa berat sebanyak 85 ART. Jumlah seluruh responden dengan gangguan jiwa berat adalah sebanyak 1.728 orang. Berdasarkan prevalensi psikosis tertinggi di Metro (1.8 permil) dan terendah di Tulangbawang ( 0.1 permil) sedangkan kabupaten Lampung timur sebesar 0,7 permil. Prevalensi

\footnotetext{
Rahma Elliya' Program Studi llmu Keperawatan Fakultas Kedokteran Universitas Malahayati Bandar Lampung.

Email: bundaauliyusri@yahoo.co.id

Sri Haryani ${ }^{2}$ UPTD Puskesmas Sidorejo Kecamatan Sekampung Udik Kabupaten Lampung Timur

Email: haryanisri3599@gmail.com

Triyoso $^{3}$ Akademi Keperawatan Malahayati Bandar Lampung. Email: triyosoalip@gmail.com
} 
Pelatihan kesehatan jiwa terhadap pengetahuan dan sikap keluarga dalam merawat pasien dengan skizofrenia

penduduk yang mengalami gangguan mental emosional tertinggi di Pesawaran (2.1\%) dan tertinggi kedua adalah Lampung Timur dan Kota Bandar Lampung masing-masing 2,0\% (Departemen Kesehatan Republik Indonesia, 2013).

Berdasarkan data tahun 2015 terdapat 213 kasus gangguan jiwa yang terlaporkan dengan jumlah kasus skizofrenia sebanyak $158(74,17 \%)$ dengan 55 orang $(25,8 \%)$ diantaranya di pasung atau pernah dipasung, tahun 2016 telah ditemukan 440 kasus dengan $220(50 \%)$ penderita skizofrenia, $69(15,6 \%)$ kasus depresi, retardasi mental 30 kasus $(6,8 \%)$, epilepsi $30(6,8 \%)$, psikotik akut $25(5,68 \%)$, gangguan mental organik $21(4,77 \%)$, gangguan jiwa anak dan remaja 20 $(4,54 \%), 25$ orang $(5,68 \%)$ diantaranya di pasung atau pernah dipasung. Sedangkan pada tahun 2017, jumlah penderita gangguan jiwa di Kabupaten Lampung Timur berjumlah 624 penderita, dengan penderita $424(67,9 \%)$ penderita skizofrenia, 83 (13,3\%) kasus depresi, gangguan mental organik $22(3,52 \%)$, retardasi mental 30 kasus $(4,8 \%)$, psikotik akut $25(4 \%)$, gangguan jiwa anak dan remaja $20(3,2 \%), 20$ orang $(5,68 \%)$ diantaranya di pasung atau pernah dipasung (Dinas Kesehatan Lampung Timur, 2017).

Pada tahun 2015 ada 16 kasus dengan 14 orang $(87,5 \%)$ penderita Skizofrenia dan 2 orang (12,5\%) dengan dimensia, tahun 2016 ditemukan 14 kasus dengan penderita Skizofrenia dan berkembang menjadi 35 kasus dengan 34 orang $(97,1 \%)$ penderita Skizofrenia dan 1 orang $(2,9 \%)$ dengan dimensia pada tahun 2017, dan di tahun 2018 berdasarkan data terakhir sebanyak 42 kasus dengan 41 orang $(97,6 \%)$ dengan penderita Skizofrenia dan 1 orang $(2,3 \%)$ dengan penderita dimensia (Dinas Kesehatan Lampung Timur, 2018).

Keluarga merupakan faktor yang sangat penting dalam proses kesembuhan klien yang mengalami gangguan jiwa. Sikap keluarga bermanfaat untuk perkembangan menuju kepribadian yang sehat tanpa gangguan. Apabila sikap semacam ini tidak ada, maka keberhasilan penyembuhan sangat berkurang atau bahkan tidak akan menemui hasil. Salah satu kendala dalam upaya penyembuhan pasien gangguan jiwa adalah pengetahuan masyarakat dan keluarga. Keluarga dan masyarakat menganggap gangguan jiwa adalah penyakit yang memalukan dan membawa aib bagi keluarga. Upaya pengobatan pasien gangguan jiwa dibawa berobat ke dukun atau paranormal. Tindakan keluarga dalam menangani pasien gangguan jiwa ini diakibatkan oleh kurangnya pengetahuan keluarga mengenai gangguan jiwa. Jika pengetahuan yang dimiliki lebih baik, maka penanganan dilakukan secara medis. Pengetahuan yang dimiliki keluarga mengenai penyakit gangguan jiwa dapat berasal dari berbagai sumber. Selain dari latar belakang pelatihan secara formal, informasi lain dapat berasal dari koran, televisi, majalah kesehatan, ataupun responden mendapat informasi kesehatan dari tenaga kesehatan, yang pada akhirnya akan mempengaruhi pengetahuan responden tentang gangguan jiwa. Selanjutnya sikap keluarga cenderung memperlakukan pasien gangguan kejiwaan dengan disembunyikan, diisolasi, dikucilkan bahkan sampai ada yang dipasung. Hal berbeda jika keluarga bersikap mendukung dengan melakukan pengobatan ke rumah sakit jiwa. Hal ini sangat membantu kesembuhan klien dan menghambat kekambuhan (Kusumaningtyas, Widodo, \& Kartinah, 2017).

Penelitian terkait menyimpulkan terdapat perbedaan yang signifikan pengetahuan, sikap dan intensi tentang perawatan pasien paska pasung sebelum dan setelah mendapatkan pelatihan kesehatan pada kader kesehatan jiwa. Pemberian pelatihan kesehatan terbukti efektif terhadap peningkatan pengetahuan, sikap dan intensi tentang perawatan pasien paska pasung (Setyawan, \& Widodo, 2017).

Berdasarkan hasil pra survey yang dilakukan peneliti di UPTD Puskesmas Sidorejo diperoleh data sebanyak 42 orang yang mengalami gangguan jiwa dengan rincian sebanyak 41 orang $(97,6 \%)$ mengalami skizofrenia dan sebanyak 1 orang $(2,4 \%)$ mengalami demensia sampai desember 2018. Hasil wawancara yang dilakukan terhadap 5 keluarga yang memiliki pasien dengan gangguan jiwa terdapat 4 orang mengatakan malu memiliki keluarga yang menderita gangguan jiwa dengan skizofrenia dan keluarga juga belum tahu cara untuk melakukan perawatan dan penanganan darurat terhadap pasien yang menderita gangguan jiwa seperti percobaan bunuh diri, penanganan pada gangguan jiwa ringan, sedang, dan berat dirumah, dan sikap yang dilakukan apabila pasien tidak mau rutin minum obat sehingga langkah terbaik menurut keluarga untuk mengatasi supaya

\footnotetext{
Rahma Elliya' Program Studi llmu Keperawatan Fakultas Kedokteran Universitas Malahayati Bandar Lampung. Email: bundaauliyusri@yahoo.co.id

Sri Haryani ${ }^{2}$ UPTD Puskesmas Sidorejo Kecamatan Sekampung Udik Kabupaten Lampung Timur

Email: haryanisri3599@gmail.com

Triyoso $^{3}$ Akademi Keperawatan Malahayati Bandar Lampung. Email: triyosoalip@gmail.com
} 
Pelatihan kesehatan jiwa terhadap pengetahuan dan sikap keluarga dalam merawat pasien dengan skizofrenia

tidak mengganggu orang lain maka keluarga melakukan pemasungan, menurut keluarga langkah ini tepat agar pasien tidak akan membuat onar di masyarakat dan tidak membuat malu keluarga.

Penelitian ini didasari pada teori pengetahuan, pengetahuan merupakan salah faktor yang paling berpengaruh terhadap perubahan sikap, dimana semakin baik pengetahuan seseorang diharapkan sikap yang terbentuk juga akan semakin baik. Upaya untuk meningkatkan peran anggota keluarga yaitu dengan pelatihan kesehatan yang dilakukan dengan menggunakan metode penyuluhan kesehatan tentang cara perawatan dan penanganan pasien dengan gangguan jiwa menggunakan teknik ceramah, wawancara, demonstrasi. Sedangkan pemilihan wilayah kerja UPTD Puskesmas Sidorejo Kabupaten Lampung Timur sebagai tempat penelitian didasari kejadian skizofrenia yang ditangani masih dibawah Standar Pelayanan Minimal Dinas Kesehatan Kabupaten Lampung Timur Tahun 2018 mencapai 100\% tertangani, sedangkan dari jumlah pasien yang terdeteksi gangguan jiwa sebanyak 42 Kasus dengan penanganan kasus berupa kunjungan rumah sebanyak 20 kasus $(47,62 \%)$. Hasil tersebut masih dibawah Standar Pelayanan Minimal dan masih banyak penderita yang dikucilkan oleh masyarakat seperti masyarakat tidak mau bergaul dengan orang yang mengalami gangguan jiwa, tidak diikutsertakan dalam kegiatan di masyarakat dan mengolok-olok orang tersebut selain itu jumlah pasien dengan gangguan jiwa semakin tahun semakin meningkat.

\section{METODE PENELITIAN}

Jenis penelitian kuantitatif dengan menggunakan rancangan quasi eksperimen, objek dalam penelitian ini keluarga dengan pasien Skizofrenia, subjek dalam penelitian ini adalah pengetahuan dan sikap sebelum dan setelah dilakukan pelatihan kesehatan. Penelitian dilaksanakan di UPTD Puskesmas Sidorejo
Kecamatan Sekampung Udik Kabupaten Lampung Timur pada bulan Januari-Maret tahun 2019. Populasi dalam penelitian ini sebanyak 41 keluarga. Sampel pada penelitian ini sebanyak 20 orang yang diberikan intervensi pelatihan kesehatan.

Alat pengumpulan data pada penelitian ini adalah kuesioner yang mengacu pada kerangka konsep yang telah dibuat yaitu berpedoman pengaruh pelatihan kesehatan jiwa terhadap pengetahuan dan sikap pada keluarga dengan Skizofrenia. Kuesioner untuk pengetahuan berisi 20 soal tentang tingkat pengetahuan keluarga dengan gangguan jiwa dan 20 pernyataan tentang sikap keluarga dengan gangguan Jiwa. Cara Pengumpulan data dilakukan dengan melakukan penyuluhan dalam waktu satu hari yang menggunakan bantuan enumerator dalam pelaksanaan ini adalah petugas Promkes di puskesmas yang mempunyai kualifikasi yang sama dengan peneliti yaitu pelatihan petugas promosi kesehatan lulusan DIII Keperawatan, mempunyai kompetensi yang sama, mempunyai persepsi dan tujuan yang sama tentang pemberian Penkes tentang gangguan jiwa ini.

Selanjutnya dilakukan pre test dengan membagikan lembar kuesioner terlebih dahulu sebelum acara penyuluhan dimulai, diisi sesuai dengan pemahaman masing-masing individu dan hasilnya diberi skoring sebagai hasil dari pre test untuk variabel pengetahuan dan sikap. Kemudian memberikan penyuluhan kepada keluarga yang memiliki pasien dengan gangguan jiwa Skizofrenia serta masyarakat dengan penyampaian materi tentang perawatan pasien dengan gangguan jiwa, sesuai dengan Satuan Acara Penyuluhan (SAP), dan dilanjutkan tanya jawab. Langkah terakhir melakukan post test dengan mengisi kembali lembar kuesioner dengan pertanyaan yang sama dengan lembar kuesioner pada saat pre test, dan hasilnya diberi skoring sebagai hasil dari post test untuk variabel pengetahuan dan sikap.

\footnotetext{
Rahma Elliya' Program Studi llmu Keperawatan Fakultas Kedokteran Universitas Malahayati Bandar Lampung. Email: bundaauliyusri@yahoo.co.id

Sri Haryani ${ }^{2}$ UPTD Puskesmas Sidorejo Kecamatan Sekampung Udik Kabupaten Lampung Timur

Email: haryanisri3599@gmail.com

Triyoso ${ }^{3}$ Akademi Keperawatan Malahayati Bandar Lampung. Email: triyosoalip@gmail.com
} 
Pelatihan kesehatan jiwa terhadap pengetahuan dan sikap keluarga dalam merawat pasien dengan skizofrenia

HASIL

Tabel 1. Rata-Rata Pengetahuan Keluarga Tentang Skizofrenia N = 20

\begin{tabular}{cccccc}
\hline Variabel & Mean & SD & Min & Max & Cl 95\% \\
\hline $\begin{array}{c}\text { Pengetahuan sebelum } \\
\begin{array}{c}\text { Pelatihan kesehatan } \\
\text { Pengetahuan sesudah } \\
\text { Pelatihan kesehatan }\end{array}\end{array}$ & 11,05 & 1,468 & 8 & 14 & $10.36-11.74$ \\
\hline
\end{tabular}

Berdasarkan tabel 1. diatas pengetahuan sebelum pelatihan kesehatan adalah 11,05 dengan standar deviasi 1,468 dan pengetahuan sesudah pelatihan kesehatan adalah 18.75 dengan standar deviasi 0.967 .

Tabel 2. Rata-Rata Sikap Tentang Skizofrenia N = 20

\begin{tabular}{lccccc}
\hline \multicolumn{1}{c}{ Variabel } & Mean & SD & Min & Max & Cl 95\% \\
\hline $\begin{array}{l}\text { Sikap Sebelum Pelatihan } \\
\text { kesehatan }\end{array}$ & 48.0 & 2.991 & 43 & 53 & $46.60-49.40$ \\
$\begin{array}{l}\text { Sikap sesudah Pelatihan } \\
\text { kesehatan }\end{array}$ & 74.70 & 2.716 & 70 & 80 & $73.43-75-97$ \\
\hline
\end{tabular}

Berdasarkan tabel 2. diatas sikap sebelum pelatihan kesehatan adalah 48.0 dengan standar deviasi 2.991 dan sikap sesudah pelatihan kesehatan adalah 74.70 dengan standar deviasi 2.716 .

Tabel 3. Pengaruh Pelatihan Kesehatan Jiwa Terhadap Pengetahuan Keluarga N = 20

\begin{tabular}{lccccc}
\hline \multicolumn{1}{c}{ Variabel } & N & Mean & SD & t-test & p-Value \\
\hline $\begin{array}{l}\text { Pengetahuan } \\
\text { sebelum } \\
\text { pelatihan } \\
\text { kesehatan }\end{array}$ & 20 & 11,05 & & & \\
$\begin{array}{l}\text { Pengetahuan } \\
\text { sesudah } \\
\text { pelatihan } \\
\text { kesehatan }\end{array}$ & 20 & 18,75 & & & \\
\hline
\end{tabular}

Berdasarkan tabel 3. diatas, hasil uji statistik didapatkan $t_{\text {-test }}>t$ tabel, $23.106>1.684, p$-value $=0,000$ ( $p$-value $<\alpha=0,05$ ) yang berarti ada pengaruh pelatihan kesehatan jiwa terhadap pengetahuan keluarga dengan pasien Skizofrenia. Berdasarkan hasil terlihat bahwa, pada kelompok sesudah diberikan pelatihan kesehatan memiliki kenaikan tingkat pengetahuan dengan selisih rata-rata 7.7 .

Rahma Elliya' Program Studi llmu Keperawatan Fakultas Kedokteran Universitas Malahayati Bandar Lampung.

Email: bundaauliyusri@yahoo.co.id

Sri Haryani ${ }^{2}$ UPTD Puskesmas Sidorejo Kecamatan Sekampung Udik Kabupaten Lampung Timur

Email: haryanisri3599@gmail.com

Triyoso $^{3}$ Akademi Keperawatan Malahayati Bandar Lampung. Email: triyosoalip@gmail.com 
Pelatihan kesehatan jiwa terhadap pengetahuan dan sikap keluarga dalam merawat pasien dengan skizofrenia

Tabel 4. Pengaruh Pelatihan Kesehatan Jiwa Terhadap Sikap Keluarga N = 20

\begin{tabular}{llllll}
\hline \multicolumn{1}{c}{ Sikap } & N & $\begin{array}{l}\text { Beda } \\
\text { Mean }\end{array}$ & SD & t-test & $p$-Value \\
\hline $\begin{array}{l}\text { Sikap sebelum } \\
\text { pelatihan } \\
\text { kesehatan }\end{array}$ & 20 & 48,00 & & & \\
$\begin{array}{l}\text { Sikap sesudah } \\
\text { pelatihan } \\
\text { kesehatan }\end{array}$ & 20 & 74,70 & & & \\
\hline
\end{tabular}

Berdasarkan tabel 4. diatas, hasil uji statistik didapatkan $t_{\text {-test }}>t_{\text {tabel, }}, 23.106>1.684, p$-value $=0,000$ ( $p$-value $<\alpha=0,05)$ yang berarti ada pengaruh pelatihan kesehatan jiwa terhadap sikap keluarga dengan pasien Skizofrenia. Berdasarkan hasil terlihat bahwa, pada kelompok sesudah diberikan pelatihan kesehatan memiliki kenaikan sikap dengan selisih rata-rata 26.7.

\section{PEMBAHASAN}

\section{Pelatihan Kesehatan Terhadap Pengetahuan Pada Keluarga}

Berdasarkan hasil penelitian diperoleh $\mathrm{t}_{\text {-test }}>\mathrm{t}$ tabel, 23.106> 1,684, $p$-value $=0,000$, maka dapat disimpulkan bahwa ada pengaruh pelatihan kesehatan jiwa terhadap pengetahuan keluarga dengan pasien Skizofrenia. Penyebab terjadinya perubahan perilaku tergantung kepada kualitas stimulus yang berkomunikasi dengan organism. Artinya kualitas dari sumber komunikasi (source) menentukan keberhasilan perubahan perilaku seseorang, kelompok atau masyarakat. Stimulus yang diberikan dapat diterima atau ditolak, bila diterima berarti ada perhatian dari individu dan stimulus tersebut efektif. Apabila stimulus telah mendapat perhatian maka akan dilanjutkan pada proses berikutnya, Sesudah itu organism mengolah stimulus sehingga terjadi kesediaan untuk bertindak demi stimulus yang telah diterima , akhirnya stimulus mempunyai efek terhadap perubahan perilaku (Notoadmotjo, 2012).

Kekambuhan pasien dengan skizofrenia dapat terjadi karena berbagai faktor, dan salah satunya karena perilaku keluarga yang tidak mempunyai pengetahuan yang cukup bagaimana cara menangani pasien dengan skizofrenia selama di rumah (Pribadi, Yansuri, \& Maulana, 2019).

Sebagai salah satu langkah untuk meningkatkan pengetahuan masyarakat tentang kesehatan, sampai saat ini tenaga kesehatan masih menggunakan metode pelatihan kesehatan karena metode ini jika diterapkan menggunakan bahasa yang mudah dimengerti atau tidak terlalu sulit untuk dimengerti oleh sasaran, dan dalam penyampaian materi disertai media untuk mempermudah pemahaman dan untuk menarik perhatian sasaran seperti melalui poster-poster maupun leaflet telah banyak terbukti mampu meningkatkan pengetahuan masyarakat tentang berbagai masalah kesehatan. Pelatihan kesehatan kesehatan adalah gabungan berbagai kegiatan dan kesempatan yang berlandaskan prinsip-prinsip belajar untuk mencapai suatu keadaan, dimana individu, keluarga, kelompok atau masyarakat secara keseluruhan ingin hidup sehat, tahu bagaimana caranya dan melakukan apa yang bisa dilakukan, secara perseorangan maupun secara kelompok dan meminta pertolongan bila perlu (Mubarak, 2012).

Pelatihan yaitu suatu usaha untuk mengembangkan kepribadian dan kemampuan di dalam dan di luar sekolah dan berlangsung seumur hidup. Semakin tinggi tingkat pelatihan maka cenderung seseorang akan lebih mudah mendapatkan informasi. Pelatihan adalah salah satu faktor yang dapat mempengaruhi pengetahuan seseorang. Pengetahuan dapat dipengaruhi oleh usia dapat mempengaruhi daya tangkap dan pola fikir seseorang. Semakin bertambah usia semakin berkembang pula daya pikir dan daya tangkap, sehingga pengetahuan yang diperoleh semakin baik. Beberapa teori juga berpendapat ternyata $I Q$ seseorang akan menurun cepat sejalan dengan bertambahnya umur (Budiman, 2013).

Rahma Elliya' Program Studi llmu Keperawatan Fakultas Kedokteran Universitas Malahayati Bandar Lampung.

Email: bundaauliyusri@yahoo.co.id

Sri Haryani ${ }^{2}$ UPTD Puskesmas Sidorejo Kecamatan Sekampung Udik Kabupaten Lampung Timur

Email: haryanisri3599@gmail.com

Triyoso $^{3}$ Akademi Keperawatan Malahayati Bandar Lampung. Email: triyosoalip@gmail.com 
Pelatihan kesehatan jiwa terhadap pengetahuan dan sikap keluarga dalam merawat pasien dengan skizofrenia

Lingkungan adalah segala sesuatu yang ada di sekitar individu, baik lingkungan fisik, biologis, maupun sosial, lingkungan berpengaruh terhadap proses masuknya pengetahuan ke dalam individu yang berada dalam lingkungan tersebut. Hal ini terjadi karena adanya interaksi timbal balik ataupun tidak yang akan direspon sebagai pengetahuan oleh setiap individu. Seseorang yang hidup dalam lingkungan yang cenderung berpikir luas maka pengetahuannya akan lebih baik dari pada orang yang tinggal di lingkungan yang berpikir sempit (Syafrudin, \& Delmaifanis, 2011).

Berdasarkan hasil analisis diatas pembentukan pengetahuan dapat dipengaruhi dari berbagai faktor tidak hanya dari informasi yang didapat selama pelatihan kesehatan namun juga ada faktor lain seperti pelatihan, usia, lingkungan dan lain-lain sehingga dari tingkat pengetahuan ini terdapat beberapa perbedaan kondisi masyarakat dan kepercayaan masyarakat terhadap kesehatan, yang pada akhirnya mengubah pengetahuan masyarakat tentang skizofrenia, tingginya arus informasi yang diterima masyarakat setempat, rendahnya tingkat pengetahuan masyarakat mengenai skizofrenia disebabkan oleh kurangnya informasi yang di dapat oleh masyarakat tentang skizofrenia seperti informasi mengenai cara deteksi dini, pengobatan, anggapan masyarakat tentang biaya untuk pemeriksaan pendeteksian skizofrenia yang mahal, masalah lain dalam pendeteksian skizofrenia adalah karena malu ketika mengetahui bahwa keluarga mengalami skizofrenia.

Hasil penelitian terkait yang diperoleh yaitu menunjukan terdapat pengaruh yang signifikan antara sikap dan pengetahuan sebelum dan sesudah diberikan promosi kesehatan dengan Sig. (2-tailed) 0.000 (Aji, \& Widodo, 2016). Hasil penelitian terkait yang diperoleh yaitu karena nilai $p$ value $<0,05(0,000<0,05)$, maka diambil kesimpulan uji terdapat perbedaan pre test dan post test pengetahuan. Nilai rata-rata pre test pengetahuan adalah 13,43 dan post test sebesar 15,50. Berdasarkan nilai rata-rata pengetahuan nampak bahwa nilai post test pengetahuan lebih tinggi dibandingkan nilai pre test pengetahuan (Kusumaningtyas, Widodo, \& Kartinah, 2017).

Menurut pendapat peneliti pelatihan kesehatan yang dilakukan dalam penelitian ini telah memberikan perubahan pada pengetahuan Skizofrenia pada keluarga penderita skizofrenia yang fungsi secara luas untuk meningkatkan derajat kesehatan keluarga penderita skizofrenia itu sendiri. Seseorang yang memiliki pengetahuan yang tinggi terhadap skizofrenia maka dia sadar tentang pentingnya menjaga kesehatan jiwa, yang selanjutnya merasa tertarik dan akan menimbang baik buruknya yang selanjutnya akan melakukan pemeriksaan secara rutin, mendukung penderita untuk mengkonsumsi obat sesuai anjuran. Pengetahuan terjadi karena adanya kebutuhan seseorang yang harus segera dipenuhi untuk segera beraktifitas segera mencapai tujuan. Pengetahuan itu muncul karena adanya kebutuhan dalam rangka memenuhi suatu tujuan.

\section{Pelatihan Kesehatan Terhadap Sikap Pada Keluarga}

Berdasarkan hasil penelitian diketahui $t_{\text {-test }}>\mathrm{t}$ tabel, 23.106 $>1.684, p$-value $=0,000$ ( $p$-value $<\alpha=$ 0,05 ) yang berarti ada pengaruh pelatihan kesehatan jiwa terhadap sikap keluarga dengan pasien Skizofrenia. Berdasarkan hasil terlihat bahwa, pada kelompok sesudah diberikan pelatihan kesehatan memiliki kenaikan sikap dengan selisih 26.7 .

Sesudah seseorang mengetahui stimulus atau objek proses selanjutnya akan menilai atau bersikap terhadap stimulus. Apabila individu mempunyai sikap yang positif terhadap stimulus maka ia akan mempunyai sikap yang menunjukkan atau memperlihatkan, menerima, mengakui, menyetujui serta melaksanakan norma - norma yang berlaku dimana individu tersebut berada. Demikian sebaliknya bila individu mempunyai sikap yang negatif, individu tersebut akan menolak norma - norma yang berlaku dimana individu tersebut berada (Notoatmodjo, 2010).

Sikap dapat berupa evaluasi umum yang dibuat manusia terhadap dirinya sendiri, orang lain, obyek atau isue. berbagai faktor yang mempengaruhi sikap menjadi positif atau negatif, yaitu pengalaman pribadi, pengaruh orang ain yang dianggap penting, pengaruh kebudayaan, media massa, lembaga pelatihan dan lembaga agama, faktor emosional (Azwar, 2016).

Sikap responden terhadap keluarga dengan penderita skizofrenia didorong oleh banyak faktor, salah satunya adalah budaya, karena kebudayaan dimana kita hidup dan dibesarkan mempunyai pengaruh besar terhadap pembentukan sikap kita. Kebudayaan telah menanamkan garis pengaruh sikap kita terhadap berbagai masalah.

Rahma Elliya' Program Studi llmu Keperawatan Fakultas Kedokteran Universitas Malahayati Bandar Lampung.

Email: bundaauliyusri@yahoo.co.id

Sri Haryani ${ }^{2}$ UPTD Puskesmas Sidorejo Kecamatan Sekampung Udik Kabupaten Lampung Timur

Email: haryanisri3599@gmail.com

Triyoso $^{3}$ Akademi Keperawatan Malahayati Bandar Lampung. Email: triyosoalip@gmail.com 
Pelatihan kesehatan jiwa terhadap pengetahuan dan sikap keluarga dalam merawat pasien dengan skizofrenia

Kebudayaan telah mewarnai sikap anggota masyarakat, karena kebudayaanlah yang memberi corak pengalaman individu-individu yang menjadi anggota kelompok masyarakat hanya kepribadian individu yang telah mapan dan kuat yang dapat memudarkan dominan kebudayaan dalam pembentukan sikap individual (Yosep, 2009).

Berdasarkan penelitaian terkait hasil uji Paired sample t-test sikap diperoleh nilai thitung 7,711 dan nilai signifikansi sebesar 0,000 . Karena nilai $p$ value $<0,05(0,000<0,05)$, maka diambil kesimpulan uji terdapat perbedaan pre test dan post test sikap. Nilai rata-rata pre test sikap adalah 36,83 dan post test sebesar 44,43. Berdasarkan nilai rata-rata sikap nampak bahwa nilai post test sikap lebih tinggi dibandingkan nilai pre test sikap (Kusumaningtyas, Widodo, \& Kartinah, 2017).

Berdasarkan Penelitian terkait menunjukkan hasil sikap responden dengan jumlah 37 , sebelum dilakukan pelatihan kesehatan didapatkan nilai rata-rata sebesar 50.97, nilai tersebut termasuk kategori sedang. Sedangkan untuk nilai rata-rata sesudah dilakukan pelatihan kesehatan sebesar 54.62, nilai tersebut tergolong baik. Hasil uji statistik dengan menggunakan Paired samples $t$ test menunjukan, terdapat pengaruh pelatihan kesehatan sikap keluarga dan masyarakat, dengan Sig. (2-tailed) 0.000 dimana jika nilai probabilitas < 0.05 maka hipotesis atau HO ditolak (Aji, \& Widodo, 2016).

Berbagai bentuk kesalahan sikap masyarakat dalam merespon kehadiran penderita gangguan jiwa dalam hal ini adalah penderita skizofrenia terjadi akibat konstruksi pola berpikir yang salah akibat ketidaktahuan publik. Terdapat logika yang salah di masyarakat, kondisi mispersepsi tersebut selanjutnya berujung pada tindakan yang tidak membantu percepatan kesembuhan si penderita. Masyarakat cenderung menganggap orang dengan kelainan mental atau gangguan jiwa sebagai sampah sosial (Dalami, Suliswati, Farida, Rochimah, \& Banon, 2009).

Dari hasil penelitian yang dilakukan dengan pemberian arahan dan sosialisasi berupa pelatihan kesehatan pada responden dapat merubah sikap negatif tersebut. Sikap responden tentang skizofrenia sebelum dan sesudah dilakukan pelatihan kesehatan mengalami peningkatan kearah sikap yang lebih positif dengan hasil terjadi perubahan sikap oleh responden terhadap keluarga yang mengalami Skizofrenia yaitu mereka mulai tidak bersikap acuh tak acuh, peduli dengan keadaan penderita, dapat menerima keadaan penderita, memberikan perhatian serta mengupayakan perawatan dan pengobatan secara rutin terhadap penderita, keluarga memberikan tempat yang layak terhadap penderita, dan keluarga mulai mengajak penderita dalam kegiatan sosial di masyarakat, serta keluarga memberikan dukungan dan motivasi.

\section{SIMPULAN}

Diketahui bahwa pada kelompok sesudah diberikan pelatihan kesehatan memiliki kenaikan tingkat pengetahuan dengan selisih 7.7, dengan hasil uji statistik didapatkan $t$-test $>t$ tabel, 23.106> $1.684, p$-value $=0,000$ ( $p$-value $<a=0,05)$. Serta pada kelompok sesudah diberikan pelatihan kesehatan memiliki kenaikan sikap dengan selisih 26.7, hasil uji statistik didapatkan $t$-test $>t$ tabel, 23.106> 1.684, $p$-value $=0,000(p$-value $<a=$ $0,05)$.

\section{SARAN}

Perlu lebih meningkatkan intensitas pelatihan kesehatan seperti penyuluhan kesehatan dilaksanakan $3 x$ dalam sebulan serta dilakukan kunjungan rumah secara rutin oleh petugas kesehatan terdiri dari perawat, dokter, maupun aparat desa.

\section{DAFTAR PUSTAKA}

Aji, H. P. B., \& Widodo, A. K. (2016). Pengaruh Pendidikan Kesehatan Terhadap Pengetahuan dan Sikap Keluarga dan Masyarakat yang Terdapat Pasien Pasca Pasung di Tawangsari(Doctoral dissertation, Universitas Muhammadiyah Surakarta).

Azwar, S. (2016). Sikap Manusia dan Pengukurannya, edisi 2. Pustaka Pelajar, Yogyakarta.

Budiman, R. A. (2013). Kapita selekta kuesioner pengetahuan dan sikap dalam penelitian kesehatan. Jakarta: Salemba Medika, P4-8.

Dalami, E. Suliswati., Farida, P., Rochimah., \& Banon, E.(2009). Asuhan Keperawatan Jiwa dengan Masalah Psikososial.

\footnotetext{
Rahma Elliya' Program Studi llmu Keperawatan Fakultas Kedokteran Universitas Malahayati Bandar Lampung. Email: bundaauliyusri@yahoo.co.id

Sri Haryani ${ }^{2}$ UPTD Puskesmas Sidorejo Kecamatan Sekampung Udik Kabupaten Lampung Timur

Email: haryanisri3599@gmail.com

Triyoso $^{3}$ Akademi Keperawatan Malahayati Bandar Lampung. Email: triyosoalip@gmail.com
} 
Pelatihan kesehatan jiwa terhadap pengetahuan dan sikap keluarga dalam merawat pasien dengan skizofrenia

Departemen Kesehatan Republik Indonesia. (2013). Laporan hasil riset kesehatan dasar (RISKESDAS) Nasional.

Dinas Kesehatan Lampung Timur. (2017). Profil Kesehatan Dinas Kesehatan Kabupaten Lampung Timur.

Dinas Kesehatan Lampung Timur. (2018). Profil Kesehatan UPTD Puskesmas Sidorejo Kecamatan Sekampung Udik. Lampung Timur: Puskesmas Sidorejo

Husmiati, H. (2016). Rencana Pemulangan dan Integrasi Eks Penderita Gangguan Mental dengan Masyarakat: Masalah dan Solusi. Sosio Informa, 2(1).

Kementerian Kesehatan Republik Indonesia. (2014). Stop stigma dan diskriminasi terhadap orang dengan gangguan jiwa (ODGJ). Jakarta: Kementerian Kesehatan RI. Diakses: www.depkes.go.id

Kementrian Hukum Dan Hak Asasi Manusia (2014). Undang-Undang Republik Indonesia Nomor 18 Tahun 2014 Tentang Kesehatan Jiwa. Diakses dari http://ditjenpp.kemenkumham.go.id/arsip/ln/201 $\underline{\text { 4/uu18-2014bt.pdf }}$

Kusumaningtyas, R., Widodo, A., \& Kartinah, S. K. (2017). Pengaruh Pendidikan Kesehatan Jiwa Keluarga Terhadap Pengetahuan Dan Sikap Pencegahan Kekambuhan Gangquan Jiwa Di Desa Makamhaji Kecamatan Kartasura Kabupaten Sukoharjo (Doctoral dissertation, Universitas Muhammadiyah Surakarta).

Lokko, H. N., Chen, J. A., Parekh, R. I., \& Stern, T. A. (2016). Racial and ethnic diversity in the US psychiatric workforce: a perspective and recommendations. Academic Psychiatry, 40(6), 898-904.
Mubarak, W. I. (2012). Promosi kesehatan untuk kebidanan. Jakarta: Salemba Medika, 38, 1127.

Notoatmodjo, S. (2010). Ilmu perilaku kesehatan. Jakarta: Rineka Cipta, 200, 26-35.

Notoatmodjo, S. (2012). Pendidikan dan perilaku kesehatan. Jakarta: rineka cipta, 16, 15-49.

Pribadi, T., Yansuri, Y., \& Maulana, I. (2019). Hubungan pengetahuan keluarga dengan kekambuhan pasien skizofrenia di rumah sakit jiwa Provinsi Lampung. Malahayati Nursing Journal, 1(2), 239-247.

Setyawan, M. A., \& Widodo, A. (2017). Pengaruh Pendidikan Kesehatan tentang Perawatan Pasien Gangguan Jiwa Pasca Pasung Terhadap Pengetahuan, Sikap dan Intensi Kader Kesehatan (Doctoral dissertation, Universitas Muhammadiyah Surakarta).

Suliswati, S. D., Jeremia, A., Yenny, M., \& Sumijatun, S. (2011). Konsep dasar keperawatan kesehatan jiwa. Jakarta: EGC.

Syafrudin, D. A. \& Delmaifanis. (2011). Himpunan penyuluhan kesehatan pada remaja, keluarga, lansia dan masyarakat. Jakarta: Trans Info Media (TIM).

World Health Organization. (2017). Depression and Other Common Mental Disorders : Global Health Estimates. Geneva: World Health Organization, 1-24.

Yosep, I. (2009). Keperawatan Jiwa (edisi revisi). Bandung: Refika Aditam

\footnotetext{
Rahma Elliya' Program Studi llmu Keperawatan Fakultas Kedokteran Universitas Malahayati Bandar Lampung.

Email: bundaauliyusri@yahoo.co.id

Sri Haryani ${ }^{2}$ UPTD Puskesmas Sidorejo Kecamatan Sekampung Udik Kabupaten Lampung Timur

Email: haryanisri3599@gmail.com

Triyoso ${ }^{3}$ Akademi Keperawatan Malahayati Bandar Lampung. Email: triyosoalip@gmail.com
} 